\title{
PERAN INOVASI PENDIDIKAN TERHADAP PEMBELAJARAN IPS DI ZAMAN SEKARANG
}

\section{Orm Aqil Gymmayil}

\author{
Email: aqilgymmayil@gmail.com \\ Program Studi Pendidikan Sejarah Fakultas Keguruan dan Ilmu Pendidikan \\ Universitas Lambung Mangkuurat \\ Banjarmasin
}

\begin{abstract}
Abstrak
Inovasi sendiri ialah memperkenalakan apa saja yang baru yang ada dimuka bumi ini tetapi hanya berhubungan dengan manusia yang mana tujuannya membuat perubahan kearah yang lebih baik. Dunia pendidikan pun tidak lepas dari kata inovasi yang mana banyak sekarang ini metode-metode baru berkembang guna terciptanya perubahan untuk generasi selanjutnya. pendidikan dihadapkan pada tuntutan paradigmatik untuk memerankan pendidikan dalam penguasaan ilmu dan teknologi. Tantangan ini muncul dan menuntut untuk dihadapi secara serentak, dan menuntut jawaban strategis dengan mengintegrasi kebijakan dan pembudayaan dalam kerangka peningkatan kualitas manusia Indonesia untuk menyongsong di era globalisasi melalui peningkatan mutu pendidikan. Karena Negara yang maju pastinya memiliki faktor tentang pendidikan yang baik karena dari pendidikan itulah yang menghasilkan orang-orang hebat
\end{abstract}

\section{PENDAHULUAN}


Inovasi adalah memperkenalkan ide baru atau barang baru, pelayanan baru dan cara-cara baru yang lebih bermanfaat bagi kehidupan manusia (Syafaruddin, S., dkk., 2016:24). Jadi inovasi itu merupakan kreatifitas atau penemuan yang berhubungan dengan manusia yang mana tujuannya memperkenalkan apa yang baru atau hal-hal mengenai perubahan untuk menuju kearah yang lebih baik lagi.

Sedangkan pengertian dari inovasi Pendidikan ialah (Rusdiana, 2014:46) menjelaskan inovasi pendidikan adalah inovasi untuk memecahkan masalah dalam pendidikan, dalam hal ini mencakup hal-hal yang berhubungan dengan komponen sistem pendidikan baik dalam arti sempit yaitu tingkat lembaga pendidikan maupun arti luas yaitu sistem pendidikan nasional. Sebenarnya inovasi pendidikan ialah ide atau pemikiran yang baru yang mana tujuannya ditujukan kepada pendidikan agar mempermudah pembelajaran pada saat sedang berlangsung. Yang mana adanya inovasi ini lebih ditujukan kepada pengajar (guru), sebab guru lah yang akan menerapkan inovasi apa yang akan di ajarkan kepada peserta didiknya.

Pendidikan IPS merupakan pembelajaran wajib yang ada di kurikulum yang mana pembelajaran IPS ini dimulai dari sekolah dasar (SD), sekolah menengah pertama (SMP/MTS), sekolah menengahah atas (SMA/SMK,MAN). Di jenjang persekolahan erat kaitannya dengan disiplin ilmu sosial yang terintegrasi dengan penetahuan lain yang dirancang secara ilmiah dan pedagogis untuk kepentingan pembelajaran. kita mengenal banyak istilah yang terkadang mengacaukan pikiran. Misalnya istilah Ilmu-ilmu Sosial (Social Sciences), Ilmu Pengetahuan Sosial (Social Studies), Pendidikan Ilmu Pengetahuan Sosial (Social Studies Education) dan Pendidikan Ilmu Sosial (Social Sciences Education). (Abbas, E. W. 2013:3).

\section{PEMBAHASAN}

Inovasi pembelajaran IPS pada hakekatnya, adalah upaya untuk memenuhi peningkatan mutu proses pendidikan yang dilakukan terus menerus, untuk memenuhi perkembangan tuntutan masyarakat terhadap pendidikan. Oleh karena itu, inovasi

tidak berarti peningkatan penyempurnaan dan pembaharuan inovasi dalam proses 
pembelajaran yang bertentangan dengan prinsip tersebut yang justru akan cepat ketinggalan dan bahkan akan menjadi penghambat, perubahan atau lambatnya proses inovasi tersebut. Dengan demikian inovasi dalam pembelajaran IPS akan efektif dilakukan, manakala ditunjuk oleh hasil evaluasi dan penelitian dalam bidang pembelajaran IPS.

Era revolusi industri 4.0 menuntut sebagian besar komponen masyarakat harus untuk mampu mengembangkan kemampuan diri agar digitalisasi benar-benar dapat terpenuhi. Oleh karena itulah, pendidikan sebagai basis utama dalam hal peningkatan kualitas sumber daya manusia yang mana mampu menghasilakan orangorang hebat. Dengan adanya internet diharapakan para peserta didik mampu menggunakan internet dengan sebaik mungkin. Yang mana adanya internet juga bisa membuat peserta didik mudah untuk mendapatkan informasi tentang pelajaran lewat aplikasi aplikasi yang di sediakan oleh pemerintah seperti perpustakaan online,yang mana ini sangat membantu sekali peserta didik apabila masih keurangan ilmu pengethuan. Adanya perpustakaan online pastinya mempermudah para peserta didik mencari buku yang berkaitan dengan pelajaran.

Di zaman teknologi yang sudah canggih ini kebanyakan orang mampu meangkases suatu pemeblajaran hanya melalu smart phone, laptop, komputer, dan lain lain. Yang mana adanya tekonologi tersebut pastinya sangat membantu sekali dalam proses pembelajaran. Yang mana sekarang ini telah banyak aplikasi-aplikasi yang mampu menunjang pembalajar siswa atau mempermudah pembelajaran. (Susanto, H., \& Akmal, H. 2018:204) Pada dasarnya, apliksi pembelajaran memiliki manfaat untuk memudahkan siswa dalam mempelajari materi tertentu. Karena sekaraang ini sedang terjadi wabah virus maka aplikas-aplikasi penunjang belajar sangat dibutuhkan agar pembelajaran bisa tetap berlangsung walau pembelajarannya bersifat daring.

Pembelajaran Ips merupakan perpaduan antara pelajaran Sejarah, Geografi, dan Sosiologi. Yang mana pembelajaran sejarah adalah melatih siswa untuk dapat memikirkan sejarah, sehingga diperlukan model penilaian khusus untuk mengetahui 
bagaimana pencapaian kemampuan siswa dalam berpikir sejarah. (Anis, M. Z. A., Putro, H. P. N., Susanto, H., dkk., 2020). Keterlibatan guru sebagai pendidik dan subjek penelitian pembelajaran adalah mutlak, dengan dukungan kemampuan profesional dan sumber daya pendidikan, dalam peran sebagai subyek dalam inovasi pembelajaran. Inovasi pembelajaran merupakan jawaban strategis untuk mengimbangi pengembangan pendidikan dengan pendekatan masalitas selama ini, sekaligus menjawab tantangan dunia pendidikan dalam membina manusia Indonesia seluruhnya, dalam era globalisasi sekarang ini.

\section{KESIMPULAN}

Inovasi pembelajaran IPS pada hakekatnya, adalah upaya untuk memenuhi peningkatan mutu proses pendidikan yang dilakukan terus menerus, untuk memenuhi perkembangan tuntutan masyarakat terhadap pendidikan. Adanya inovasi mengahasilkan apa yang nama nya teknologi,yang mana sekarang teknologi telah berkembang begitu cepat dan berdampak kepada pendidikan dan dari dampak itu juga pastinya mengahasilkan hal-hal yang positif. Yang pasti adanya inovasi pembelajaran membuat guru dan peserta didik harus lebih mengeksplor tentang hal-hal yang baru, agar pembelajaran itu tidak membuat peserta didik menjadi bosan saat pembelajaraan berlangsung, oleh karena itulah seorang guru harus mempunya banyak inovasi.

\section{REFRENSI}

Anis, M. Z. A., Putro, H. P. N., Susanto, H., \& Hastuti, K. P. (2020). Historical Thinking Model in Achieving Cognitive Dimension of Indonesian History Learning. PalArch's Journal of Archaeology of Egypt/Egyptology, 17(7), 7894-7906.

Abbas, E. W. (2013). Mewacanakan Pendidikan IPS. Mewacanakan Pendidikan IPS. 
Susanto, H., \& Akmal, H. (2018). Efektivitas Penggunaan Aplikasi Pembelajaran Berbasis Mobile Smartphone Sebagai Media Pengenalan Sejarah Lokal Masa Revolusi Fisik Di Kalimantan Selatan Pada Siswa Sekolah Menengah Atas. HISTORIA: Jurnal Program Studi Pendidikan Sejarah, 6(2), 197-206.

Syafaruddin, S., Asrul, A., Mesiono, M., Wijaya, C., \& Usiono, U. (2016). Inovasi pendidikan: suatu analisis terhadap kebijakan baru pendidikan. Perdana Publishing

Rusdiana, A. (2014). Konsep Inovasi Pendidikan. Pustaka Setia. 